\title{
Erratum to: Bifurcation analysis of the reduced model of the Bray-Liebhafsky reaction
}

\author{
Stevan Maćešićc ${ }^{1}$ Željko Čupić $^{2} \cdot$ Ljiljana Kolar-Anićc $^{1,2}$
}

\section{Erratum to: Reac Kinet Mech Cat DOI 10.1007/s11144-016-1000-2}

Due to an unfortunate mistake in the final proof correction process, Eq. 10 is displayed incorrectly in the above mentioned publication. The correct representation of Eq. 10 is published below and should be treated as definitive by the reader.

$$
\mathrm{A}+2 \mathrm{~B} \stackrel{k_{\mathrm{RA}}}{\longrightarrow} \mathrm{nB}
$$

The online version of the original article can be found under doi:10.1007/s11144-016-1000-2.

\section{Stevan Maćě̌ić}

stevan.macesic@ffh.bg.ac.rs

1 Faculty of Physical Chemistry, University of Belgrade, Studentski trg 12-16, 11158 Belgrade, Serbia

2 Department of Catalysis and Chemical Engineering, Institute of Chemistry, Technology and Metallurgy, University of Belgrade, Njegoševa 12, 11000 Belgrade, Serbia 